\title{
Peran Servicescape Terhadap Peningkatan Loyalitas Pelanggan (Kajian Empiris terhadap Pelanggan Yumaju Coffee)
}

\author{
Received: \\ 25 September \\ 2020 \\ Maya Setiawardani \\ Jurusan Administrasi Niaga, Politeknik Negeri Bandung, Indonesia
}

Revision

received: 29 Oktober 2020

Accepted:

2 November

2020

\begin{abstract}
:
The purpose of this study was to identify the servicescape that has been built by Yumaju Coffee and the level of customers' loyalty, and also to reveal how big the role of servicescape is in increasing customers' loyalty. The research method used is quantitative methods, the sampling technique uses non-probability sampling with a purposive sampling approach of 100 respondents. The data was collected through a questionnaire using a Likert scale. The data were processed using SPSS, and using descriptive analysis, correlation analysis, simple regression analysis, and analysis of the coefficient of determination, and hypothesis testing. The results of this study indicate that the servicescape built by Yumaju Coffee is categorized as good and the level of customers' loyalty is also high, and servicescape has a significant role in increasing customer loyalty by $38.1 \%$.
\end{abstract}

Keywords: coffee shop, customer's loyalty, servicescape

\begin{abstract}
Abstrak:
Tujuan penelitian ini untuk mengidentifikasikan servicescape yang telah dibangun oleh Yumaju Coffee dan tingkat loyalitas pelanggannya, serta mengungkapkan seberapa besar peran servicescape dalam meningkatkan loyalitas pelanggan. Metode penelitian yang digunakan adalah metode kuantitatif, teknik pengambilan sampelnya menggunakan nonprobability sampling dengan pendekatan purposive sampling sebanyak 100 orang responden. Pengumpulan data dilakukan melalui kuesioner dengan menggunakan skala Likert. Data diolah dengan SPSS, serta menggunakan analisis deskriptif, analisis korelasi, analisis regresi sederhana, dan analisis koefisien determinasi, serta uji hipotesis. Hasil penelitian ini menunjukkan bahwa servicescape yang dibangun oleh Yumaju Coffee termasuk dalam katagori baik dan tingkat loyalitas pelanggannya juga tinggi, serta servicescape memiliki peran yang signifikan dalam meningkatkan loyalitas pelanggannya sebesar $38,1 \%$.
\end{abstract}

Kata kunci: kedai kopi, loyalitas pelanggan, servicescape

\section{Pendahuluan}

UMKM memiliki peran penting dalam perkembangan bisnis kreatif di kota Bandung sejak tahun 2000 an dan jumlahnya terus menunjukkan pertambahan setiap tahunnya yaitu sebesar $4 \%$. Pertambahan jumlah UMKM tipe bisnis makanan dan minuman paling banyak dibandingkan dengan tipe bisnis lainnya yaitu sebesar 766 UMKM (Dinas KUMKM dan Perindag Kota Bandung, Tahun 2018). Salah satu bisnis makanan dan minuman yang banyak bermunculan saat ini adalah bisnis café/warung kopi. Pada tahun ini, ada sekitar 267 café dan warung kopi yang tersebar di kota Bandung baik di tempattempat wisata maupun di sekitaran kampus-kampus. Bahkan dalam beberapa tahun ini, Bandung beserta 
kota lainnya seperti Yogyakarta, Solo, Semarang, dan Bali ditetapkan sebagai tempat wisata makanan dan minuman yang unik dan mengesankan oleh Kementerian Pariwisata. Kota Bandung dinilai sebagai kota yang bisa menjadi destinasi trendsetter yang banyak menghadirkan beragam kuliner khususnya dalam kreasi cafe yang menyajikan kopi sebagai bahan utamanya kepada masyarakat dengan inovasi yang unik yang tidak ditemukan di kota-kota lainnya.

Yumaju Coffee adalah satu diantara warung kopi di kota Bandung. Semula Yumaju Coffee memiliki satu kedai yang berlokasi di Jl. Maulana Yusuf, kemudian mengembangkan bisnisnya dengan menambah satu kedai lagi yang berlokasi di Jl. Manado. Yumaju Coffee memiliki konsep berbeda dengan coffee shop lainnya. Coffee Shop yang satu ini mengusung tema collaboration over coffee, yang memiliki arti bahwa membangun kolaborasi sambil minum kopi. Kolaborasi ini dapat terjadi antara pemilik dengan pengunjung untuk bekerja sama misalnya mengadakan acara di coffee shop ini. Selain itu, Yumaju Coffe berbeda dengan coffee shop lainnya adalah mulai buka pk.07.00 untuk menyediakan konsumen yang membutuhkan ngopi pagi sambil sarapan, dan berakhir pk. 21.00.

Seiring dengan adanya kebiasaan baru masyarakat masa kini yang mengubah kebiasaan lama dalam memenuhi kebutuhannya, salah satunya adalah kebutuhan makanan yang cenderung pergi ke restoran cepat saji atau café atau warung kopi. Namun, ternyata café bukan hanya tempat memenuhi kebutuhan makanan saja tetapi juga kebutuhan tempat untuk berkumpul dan bersantai. Menurut Renald Kasali (dalam Pratama \& Setyorini, 2015) "ngopi" merupakan minuman pelengkap yang disukai sambil mengobrol dengan teman-teman dan kolega di warung kopi. Dan kegiatan ngopi di warung kopi ini sudah menyatu dengan gaya hidup masyarakat saat ini. Oleh sebab itu keinginan pelanggan mulai tidak terpaku hanya pada produk yang dijual, tapi juga sangat memperhatikan pelayanan dan nuansa kenyamanan ketika berada di café/warung kopi. Pada akhirnya, café bukan saja bisnis penyedia produk tapi juga penyedia jasa. Selaras dengan yang dikemukakan oleh Ongkohadi (2014), bahwa café/warung kopi adalah tempat yang enak untuk berkumpul atau sekedar bersantai dari aktivitas yang ketat sambil makan makanan ringan dan minuman dengan iringin musik sebagai hiburan tambahannya. Jadi kenyamanan lingkungan dan suasana café perlu diperhatikan pebisnis café agar pelanggan merasa betah.

Sehubungan dengan itu, berdasakan hasil penilaian dari pelanggan Yumaju Coffee melalui online adalah sebagai berikut:

Tabel 1. Hasil Penilaian Pelanggan

\begin{tabular}{|c|c|c|c|c|c|c|c|}
\hline \multirow{2}{*}{ No. } & \multirow{2}{*}{ Lokasi } & \multicolumn{6}{|c|}{ Hasil Penilaian } \\
\hline & & Rasa & Suasana & Harga:Rasa & Pelayanan & Kebersihan & Rata-rata \\
\hline 1 & $\begin{array}{l}\text { Jl.Maulana } \\
\text { Yusuf No.10 }\end{array}$ & 3,9 & 4,0 & 3,7 & 3,9 & 4,1 & 3,93 \\
\hline 2 & Jl. Manado & 3,9 & 4,2 & 3,9 & 3,9 & 3,8 & 3,93 \\
\hline
\end{tabular}

Sumber: pergikuliner.com/restaurants/bandung/yumaju-coffee, 2020

Berdasarkan informasi dari Tabel 1 menunjukkan bahwa penilaian pelanggan terhadap Yumaju Coffee secara keseluruhan rata-rata 3,93 dari 5. Sedangkan yang berkaitan dengan servicescape yaitu suasana, pelayanan, dan kebersihan memiliki nilai rata-rata 3.98 dari standar 5. Secara angka nilai ini termasuk dalam katagori cukup baik, namun hasil review dari para pelanggan menunjukkan masih terdapat kekurangan seperti tempat yang dirasakan pelanggan kurang luas sehingga bila sedang banyak pengunjung menjadi bising ditambah suara yang ditimbulkan oleh pemrosesan kopi. Selain lain, tempat parkir susah dan sempit, ukuran meja hanya cukup untuk menyimpan laptop, penerangan di tempat duduk outdoor remang-remang dan bila hujan terpaksa harus indoor. (pergikuliner.com/restaurants/bandung/yumaju-coffee, 2020). Hal ini menujukkan bahwa servicescape Yumaju Coffee belum ditata dengan maksimal.

Disamping itu, penilaian pelanggan hanya terbatas pada suasana, kebersihan, dan pelayanan. Sedangkan indikator penilaian suatu servicescape meliputi kondisi sekitar seperti penataan warna, pencahayaan, temperatur ruangan, suara, dan aroma, tata letak ruangan, bentuk peralatan dan furniture serta fungsionalitasnya, serta penataan dan keunikan interior, simbol dan tanda-tanda tertentu. Untuk itu, perlu penilaian lebih mendalam dan komprehensif terhadap penataan servicescape tersebut. 
Penilaian dan ulasan-ulasan dari pelanggan di atas menunjukkan bahwa lingkungan fisik memberikan stimulus yang direspon oleh pelanggan secara kognitif, emosional, maupun psikologis yang memberikan pengalaman positif maupun negatif (Bitner, 1992). Selanjutnya, Mehrabian \& Russell (dalam Demoulina \& Willemsb, 2019 ) mempresentasikan model yang menjelaskan efek environmental stimuli pada emosi organisme, yang kemudian mempengaruhi tanggapan organisme terhadap lingkungannya. Pelanggan yang mendapatkan pengalaman positif akan merasa puas. Sesuai dengan pendapat Anderson dan Narus (dalam Putri, 2018), bila pelanggan merasa sangat puas, maka mereka cenderung ingin mengulanginya sehingga mereka akan membeli kembali produk atau jasa yang memberikannya kepuasan tersebut. Dan hal ini akan membentuk pelanggan yang setia. Beberapa hasil penelitian yang mengungkapkan bahwa servicescape mempengaruhi loyalitas pelanggan, seperti Shashikala \& Suresh (2013) bahwa servicescape memainkan peranan penting dalam membangun loyalitas pelanggan disuatu pusat perbelanjaan. Begitu juga hasil penelitan dari Juliana \& Nouval (2020), Darvinsyah (2016), dan Oktafani dkk (2016) menyimpulkan bahwa servicescape berpengaruh secara signifikan terhadap kepuasan dan loyalitas konsumen di restoran dan jasa transportasi, dan Maeng \& Park (2015) bahwa lingkungan fisik pesawat udara yang terdiri atas spatiality, amenity, aesthetics dan entertainingness mempengaruhi secara positif terhadap loyalitas pelanggan.

Berdasarkan penjelasan di atas, bahwa lingkungan fisik mempengaruhi kepuasan dan loyalitas pelanggan. Untuk itu, perlu ada penelitian tentang peran servicescape terhadap peningkatan loyalitas pelanggan khususnya di warung kopi dimana kegiatan "ngopi" ini merupakan bagian dari gaya hidup masyarakat masa kini.

Tujuan penelitian ini untuk mengidentifikasikan servicescape yang dibangun Yumaju Coffee, tingkat loyalitas pelanggannya, serta menganalisis peranan servicescape terhadap peningakatan loyalitas pelanggan. Adapun manfaat dari hasil penelitian ini dapat memberikan gambaran tentang usaha Yumaju Coffe dalam menata servicescape yang berpengaruh terhadap loyalitas pelanggannya. Gambaran ini dapat dijadikan bahan untuk meningkatkan penataan servicescape yang disesuaikan dengan keinginan pelanggan sehingga loyalitas pelanggan meningkat.

\section{Kajian Literatur}

\section{Servicescape}

Dalam bisnis café/warung kopi, lingkungan fisik merupakan hal yang penting untuk diperhatikan karena akan membantu membentuk perasaan dan reaksi yang sesuai pada pelanggan, dan perasaan adalah pendorong utama respon pelanggan terhadap servicescape (Lovelock \& Wirtz, 2011). Café itu sendiri adalah tempat berkumpul untuk bersantai sambil makan dan minum. Seringkali para pelanggan berlama-lama duduk di café sambil mengobrol dengan teman-temannya, mengerjakan tugas, bahkan rapat. Oleh sebab itu, agar para pelanggan betah dan merasa nyaman, maka tempat café tersebut harus ditata sedemikian rupa, dilengkapi dengan fasilitas yang dibutuhkan seperti wifi, musik, dan memiliki keunikan tersendiri seperti gaya interiornya yang dapat memberikan kesan yang tidak mudah lupa bagi pelanggannya. Menurut Hightower dan Shariat (2009), sevicescape adalah suatu lingkungan yang dapat ditangkap oleh panca indra yang memberikan pengalaman bagi konsumen selama konsumen itu mendapatkan pelayanan. Sedangkan menurut Bitner (1992), servicescape merupakan lingkungan fisik suatu tempat yang memberikan pengalaman layanan bagi pelanggannya.. Lingkungan fisik ini meliputi meliputi interior dan eksterior di dalamnya. Ditambahkan juga bahwa servicescape itu merujuk pada lingkungan bukan manusia dimana layanan dilakukan, maksudnya lingkungan fisik yang ditangkap oleh pancaindra dan menciptakan kesan-kesan bagi orang-orang yang ada lingkungan tersebut. Hal ini, dapat juga diartikan sebagai lingkungan fisik tempat layanan itu diberikan dan bagaimana lingkungan tersebut berpengaruh terhadap pelanggan. Hal tersebut, selaras dengan pendapat Tombs \& MCcoll-Kennedy (dalam Liua \& Bogicevicb \& Mattila, 2018) bahwa servicecsape memiliki kekuatan mempengaruhi bagaimana perasaan pelanggan tentang pengalaman layanan yang mereka rasakan. Sedangkan menurut Milles \& Cannon (2012), servicescape diartikan sebagai gabungan dari beberapa dimensi yang mempengaruhi persepsi pelanggan secara holistic terhadap layanan.

Menurut Lovelock dan Wirtz (2009), servicescape ini berhubungan dengan keunikan dan penampilan lingkungan fisik, dan lainnya yang dijumpai konsumen ketika mereka mendapatkan pelayanan. Ditambahkan juga, menurut behavioral consequences of affect model, bahwa lingkungan 
yang menyenangkan cenderung menarik orang untuk masuk, sedangkan yang tidak menyenangkan mengakibatkan perilaku menghindar. Di Jadi servicescape memberikan rangsangan yang akan direspon oleh pelanggan. Kesimpulannya, servicescape adalah lingkungan fisik atau fasilitas fisik dimana layanan itu dilakukan yang mempengaruhi perasaan pelanggan, dan pengaruh servicescape terhadap pengalaman layanan konsumen adalah yang paling penting karena interaksi antara konsumen dan servicescape mendukung terciptanya nilai (Lunardo \& Chaney, 2016).

Menurut Bitner (dalam Lovelock \& Wirtz, 2011), ada tiga dimensi servicescape. Pertama, ambient condition (kondisi sekitar) merujuk pada karekteristik lingkungan yang dapat dirasakan oleh kelima panca indera, seperti pencahayaan, warna, musik, temperatur, dan aroma. Kedua adalah spatial layout and functionality (tata letak dan fungsionalitas) yaitu yang berhubungan dengan tata letak ruangan, bentuk peralatan dan furniture dan fungsinya, tempat parkir. Terakhir adalah sign, symbol, and artifacts ( tanda, simbol, dan artefak) yaitu yang berhubungan sinyal-sinyak baik secara eksplisit maupun implisit yang digunakan perusahaan untuk berkomunikasi dengan pelanggannya. Misalnya keunikan interior, simbol dan tanda menunjuk arah menuju toilet, jalan masuk atau keluar.

\section{Loyalitas Pelanggan}

Woodruff (dalam Srivastava \& Rai, 2018), menunjukkan bahwa penyedia layanan memandang loyalitas pelanggan sebagai sumber keunggulan bersaing yang signifikan karena loyalitas pelanggan berpengaruh secara signifikan terhadap keberhasilan dan keuntungan suatu bisnis. Loyalitas pelanggan dapat dijadikan parameter terpercaya untuk meramalkan perkembangan aktivitas pelanggan tetap dan hasil penjualannya. Menurut Makeover (dalam Kaihatu, 2007), loyalitas adalah suatu komitmen kuat membeli kembali produk atau jasa secara konsisten di masa depan. Pendapat ini selaras dengan Kotler dan Keller (2012) bahwa loyalitas adalah komitmen yang dipegang teguh untuk membeli kembali atau berlangganan produk atau jasa pilihan di masa yang akan datang walaupun pengaruh situasi dan upaya pemasaran yang memiliki potensi yang menyebabkan konsumen beralih ke produk atau jasa lain. Jadi loyalitas pelanggan adalah seseorang yang memiliki komitmen untuk melakukan pembelian ulang terhadap suatu produk atau jasa dalam jangka waktu yang panjang dan tidak terpengaruh untuk beralih ke produk atau jasa yang ditawarkan perusahaan lainnya.

Ada 4 indikator loyalitas pelanggan menurut Griffin (dalam Kaihatu, 2007). Pertama, melakukan pembelian berulang secara teratur (make regular repeat purchase) terhadap produk atau jasa dari suatu perusahaan yang dipilihnya. Kedua, membeli jenis produk atau jasa yang lain selain yang pernah dibeli (purchases another lines of product and service) yang ditawarkan oleh perusahaan yang dipilihnya.Ketiga, merekomendasikan kepada orang lain ( refers other) untuk membeli produk atau jasa di perusahaan tempat dia jadi pelanggannya. Keempat, tetap membeli produk atau jasa di tempat yang sama dan tidak tergoda oleh poduk atau jasa di tempat lainnya (demonstates an immunity to the pull of the competitor).

\section{Hubungan Servicescape dengan Loyalitas Pelanggan}

Servicescape atau lingkungan fisik dalam bisnis café sangat penting diperhatikan karena tempat atau lingkungan fisik café menjadi faktor penting untuk menarik para pelanggan. Lingkungan yang indah, tertata dengan rapih dan bersih akan menciptakan kenyaman dan kesenangan bagi para pelanggan. Dan apabila pelanggan mendapatkan kenyamanan dan kesenangan, maka akan mendapatkan kepuasan dan kepuasan yang kuat akan menciptakan loyalitas.

Sesuai dengan beberapa hasil penelitian yang menunjukkan bahwa servicescape memiliki pengaruh yang signifikan terhadap loyalitas pelanggan. Hal ini ditunjukkan dari hasil penelitan Shashikala \& Suresh (2013) bahwa servicescape memainkan peranan penting dalam membangun loyalitas pelanggan disuatu pusat perbelanjaan. Begitu juga hasil penelitan dari Juliana \& Nouval (2020), Darvinsyah (2016), dan Oktafani dkk (2016) menunjukkan bahwa servicescape memiliki pengaruh yang signifikan terhadap kepuasan dan loyalitas konsumen. Hasil penelitian lain yang dilakukan oleh Maeng \& Park (2015) menyimpulkan bahwa lingkungan fisik yang terdiri atas spatiality, amenity, aesthetics dan entertainingness memberikan pengaruh yang positif terhadap loyalitas pelanggan. Sedangakan hasil penelitian dari Halim dkk (2019) menyimpulkan bahwa servicescape berpengaruh positif terhadap loyalitas pelanggan namun tidak signifikan. 
Sehubungan dengan itu, ada keterkaitan antara servicescape dengan loyalitas pelanggan yang dapat disajikan dalam kerangka pemikiran sebagai berikut:

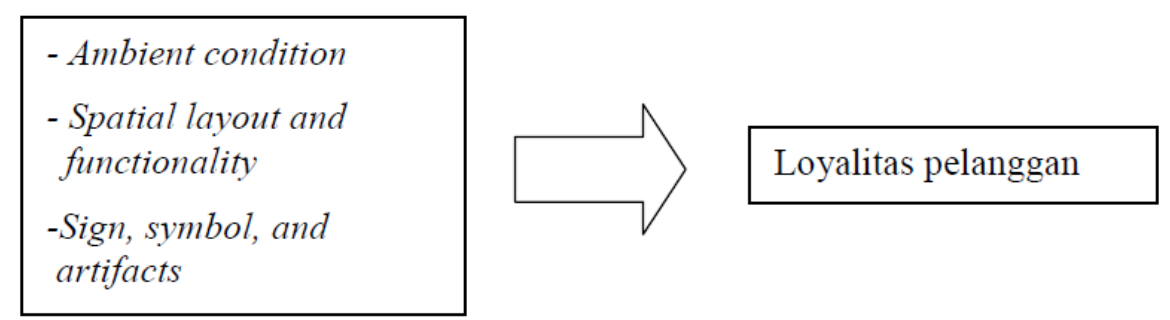

Gambar 1. Kerangka Pemikiran

Dalam penelitian ini ada dua variabel, yaitu Servicescape sebagai variable bebas (X) dan loyalitas pelanggan sebagai variabel terikat $(\mathrm{Y})$. Adapun hipotesis dalam penelitian ini adalah:

$\mathrm{H} 1$ : Adanya peran servicescape $(\mathrm{X})$ yang signifikan dalam meningkatkan loyalitas pelanggan $(\mathrm{Y}) \mathrm{di}$ Yumaju Coffee.

Ho : Tidak adanya peran servicescape (X) dalam meningkatkan loyalitas pelanggan (Y) di Yumaju Coffee.

\section{Metode Penelitian}

Pendekatan kuantitatif digunakan dalam penelitian ini untuk mengidentifikasikan servicescape yang telah dibangun oleh Yumaju Coffee dan mengidentifikasikan tingkat loyalitas pelanggannya, dan selanjutnya menganalisis sejauhmana peranan servicescape dalam meningkatkan loyalitas pelanggan Yumaju Caffee. Data dikumpulkan dengan menggunakan kuesioner dalam bentuk Google Form yang didasarkan pada skala Likert dengan lima tingkatan pilihan, dilengkapi dengan observasi dan ulasanulasan/review pelanggan dan follower instagram Yumaju Coffee melalui online.

Populasi dalam penelitian ini adalah semua pelanggan Yumaju Coffee, baik pelanggan Yumaju Coffee yang berlokasi di Jl. Maulana Yusuf No. 10 Trunojoyo maupun di Jl. Manado, Riau kota Bandung yang jumlahnya tidak diketahui. Menurut Hair (2010), jika jumlah populasi tidak diketahui (infinite population), maka jumlah sampel minimum adalah jumlah item pertanyaan dalam kuesioner dikalikan 5 sampai dengan 10. Penelitian ini terdiri dari 21 pertanyaan dan akan menggunakan pengali angka 5. Hasil perhitungan didapat 110 responden. Teknik pengambilan sampel menggunakan sampel pertimbangan yaitu dipilih berdasarkan pertimbangan tertentu untuk memperoleh satuan sampling yang memiliki karakter yang diinginkan. Sampel yang dipilih adalah pelanggan yang pernah berkunjung ke Yumaju Coffee minimal satu kali. Namun, setelah diujicobakan kepada 30 responden ternyata ada 1 item yang tidak valid sehingga dikeluarkan. Selanjutnya jumlah item yang digunakan sebanyak 20 dan jumlah responden menjadi 100 orang.

Data diolah dengan menggunakan program SPSS versi 32.0 dan analisis data dari hasil kuesioner menggunakan analisis deskriptif untuk mengetahui penataan servicescape yang telah dilakukan Yumaju Coffee dan tingkat loyalitas pelanggannya. Sedangkan untuk mengetahui besarnya peran servicescape terhadap loyalitas pelanggan, pertama menggunakan analisis korelasi untuk mengetahui hubungan antar kedua variabel tersebut, kemudian pengaruhnya dengan menggunakan analisis regresi sederhana dan koefisiensi determinasi, serta uji hipotesis.

\section{Hasil dan Pembahasan}

Hasil penelitian yang akan dibahas adalah demografi responden, deskriptif variabel serviescapes, deskriptif variabel loyalitas pelanggan, hasil perhitungan korelasi dan regresi, pengujian hipotesis dan pembahasannya.

\section{Demografi Responden}

Responden dalam penelitian ini sebanyak 100 pelanggan, dan mengungkapkan bahwa pelanggan Yumaju Coffee berjenis kelamin perempuan 56\% dan laki-laki 44\% dengan rentang usia terbanyak 21 -25 tahun sebanyak $49 \%$ disusul $>30$ sebanyak 33\%. Pelanggan terbanyak adalah karyawan sebanyak 
47\% disusul pelajar dan mahasiswa sebesar 21\%. Penghasilan terbanyak > Rp.4.000.000 sebesar 54\% disusul penghasilan antara Rp.2.500.000 - Rp.4.000.00 sebesar $22 \%$.

\section{Uji Ketepatan dan Kehandalan Instrumen Penelitian}

Uji ketepatan dan kehandalan telah dilakukan dan hasilnya menunjukkan tepat/valid baik untuk variabel servicescape maupun variabel loyalitas pelanggan karena nilai Corrected Item-Total Correlation > 0,30, dan juga handal/reliable karena nilai Cronbach's Alpha variabel servicescape sebesar 0,750 serta variabel loyalitas pelanggan sebesar 0,819 .

\section{Analisis Deskriptif Variabel Servicescapes}

Hasil analisis deskriptif variabel servicescape untuk mengungkapkan servicescape yang telah dibangun Yumaju Caffee yang disajikan dalam tabel berikut ini.

Tabel 2. Statistik Deskriptif Variabel Servicescape

\begin{tabular}{|l|c|c|c|c|c|}
\hline & $\mathrm{N}$ & Min & Max & Mean & Std. Deviation \\
\hline Ambient_Conditions & 100 & 2.00 & 5.00 & 3,93 &, 680 \\
\hline Spatial_Layout_dan_Functionality & 100 & 1.00 & 5.00 & 3,88 &, 746 \\
\hline Sign_Symbols_\&_Artefacts & 100 & 2.00 & 5.00 & 4,21 &, 593 \\
\hline Servicescape & $\mathbf{1 0 0}$ & $\mathbf{1 . 0 0}$ & $\mathbf{5 . 0 0}$ & $\mathbf{4 , 0 6}$ &, $\mathbf{6 7 3}$ \\
\hline Valid N (listwise) & 100 & & & & \\
\hline
\end{tabular}

Berdasarkan Tabel 2, dimensi-dimensi pada variabel servicescape memiliki nilai mean 4,06 tergolong "baik". Dimensi sign, symbols \& artefacts memiliki nilai mean sebesar 4,21 termasuk dalam kategori "sangat baik". Sedangkan, dimensi spatial layout \& functionally tergolong "baik" dengan nilai mean terendah sebesar 3,88. Nilai standar deviasi yang diperoleh di bawah $20 \%$ dari rata-rata yaitu sebesar $16,57 \%$ yang mengindikasikan bahwa responden memiliki tingkat variasi jawaban yang rendah dan menjawab pernyataan relatif sama.

Dari hasil analisis tersebut di atas diperoleh bahwa servicescape tergolong dalam katagori baik. Hal ini mengindikasikan bahwa servicescape yang telah dibangun oleh Yumaju Coffee sudah baik. Berdasarkan hasil pengamatan, Yumaju Coffee bukan hanya tempat memenuhi kebutuhan dan minuman saja, tetapi juga menyediakan kebutuhan tempat untuk berkumpul, bersantai, mengerjakan tugas, dan rapat. Hal ini sejalan dengan data responden, bahwa sebagian besar pengunjung didominasi oleh karyawan dan mahasiswa yang seringkali menggunakan fasilitas Yumaju Coffee untuk melakukan beberapa kegiatan tersebut. Ini menjastifikasi bahwa pihak Yumaju Coffee ingin membuat para pelanggannya betah dan merasa nyaman, maka lingkungan fisik Yumaju Coffee ditata sedemikian rupa, dilengkapi dengan fasilitas yang dibutuhkan seperti wife, music, dan gaya interiornya yang dapat memberikan kesan yang tidak mudah dilupakan oleh para pengunjungnya.

Secara keseluruhan dimensi ambient conditions termasuk dalam katagori "baik" dengan nilai mean sebesar 3,93. Pernyataan yang memiliki nilai mean terbesar adalah ambient conditions 2 bernilai 4,29 dan termasuk kategori "sangat baik". Artinya, Yumaju memposisikan sebagai coffee shop yang mengutamakan lingkungan bersih dan nyaman. Sementara itu, ambient conditions dengan nilai mean rendah terdapat pada ambient conditions6 sebesar 3,37 yang tergolong pada kategori "cukup". Pernyataan ini mengandung arti,bahwa Yumaju masih memiliki kebisingan yang sedikit mengganggu. Nilai standar deviasi driperoleh 0,680 atau 17,3\%. Angka tersebut masih berada di bawah $20 \%$ yang mengindikasikan bahwa responden memiliki tingkat variasi jawaban yang rendah dan menjawab pernyataan relatif sama.

Berdasarkan hasil penelitian bahwa indikator-indikator dari ambient conditions yang mendapatkan penilaian tertinggi yaitu lingkungan bersih dan nyaman yang termasuk dalam kategori "sangat baik". Dalam konteks cafél coffee shop, lingkungan bersih dan nyaman sering menjadi nilai lebih tersendiri bagi pelaku usaha. Berdasarkan observasi peneliti, Yumaju Coffe memiliki konsep "In Love With Coffee, Healthy, Sports, Architecture, Design and People" untuk membuat pelanggan tertarik. Selaras dengan profil responden pada penelitian, mayoritas pengunjung Yumaju Coffee adalah perempuan. Banyaknya perempuan yang lebih suka ke cafe membuat Yumaju Coffe memiliki konsep yang menjadi 
pertimbangan bagi perempuan untuk berkunjung, salah satunya adalah lingkungan di Yumaju Coffee yang bersih dan nyaman. Menurut Rachman dan Kusuma (2014), nyaman merupakan kondisi psikologis dimana manusia merasa betah dan puas pada suatu tempat sehingga senang untu tinggal berlama-lama pada tempat tersebut.Hal tersebut sesuai pula dengan pendapat Hanaysha (2016), yang mengemukakan bahwa latar lingkungan yang terawat memiliki peran penting untuk meningkatkan posisi atau merek perusahaan di pasar.

Indikator-indikator yang mendapatkan penilai baik adalah tampilan warna yang didominasi warna putih membuat ruangan tampak lebih luas. Aroma-aroma baik kopi maupun lainnya seperti bau rokok tidak menggangu pelanggan karena Yumaju memiliki ruang khusus untuk perokok dan uang tanpa rokok. Suhu ruangan Yumaju Coffee baik yang indoor maupun outdoor dirasakan nyaman oleh pelanggan. Musik yang dialunkan adalah pop alternatif yang lembut sehingga menyenangkan, begitu juga pencahayaan ruangan dirasakan baik oleh pelanggan.

Penilaian terendah dari ambient conditions yaitu ada pada indikator tingkat kebisingan di dalam dan luar ruangan. Hal ini dikarenakan cafe memiliki tempat indoor dan outdoor. Bagian indoor langsung tergabung dalam satu ruangan yang sama dengan meja barista yang berkonsep modern dan padat, karena semua sajian dari makanan, biji kopi dan semuaya ditempatkan di meja barista. Sedangkan di bagian outdoor, para pengunjung dapat menikmati kopi secara langsung di bawah pohon rindang yang menjadi daya tarik tersendiri bagi pelanggan Yumaju Coffee. Akan tetapi, dikarekanakan letak Yumaju Coffee berada di pinggir jalan utama yang sering dilewati kendaraan, maka terkadang membuat suasana di outdoor menjadi sedikit terganggu oleh suara kendaraaan.

Secara keseluruhan dimensi spartial layout and functionality juga termasuk katagori 'baik'. dengan nilai mean sebesar 3,88. Indikator yang memiliki mean terbesar adalah spatial layout and functionality 1 sebesar 4,05 yang merupakan pengaturan tata letak barang atau furniture secara menarik dan dapat pula memudahkan pergerakan pengunjung yang tergolong "baik". Sementara itu, spatial layout and functionality terendah adalah spatial layout and functionality5 yang merupakan fasilitas tempat parkir sebesar 3,42 yang tergolong "baik" juga. Nilai standar deviasi yang diperoleh 0,746 atau $19,2 \%$. Angka tersebut masih berada di bawah $20 \%$ yang mengindikasikan bahwa responden memiliki tingkat variasi jawaban yang rendah dan menjawab pernyataan relatif sama. Penataan tata letak barang/peralatan/furniture yang menarik dan memudahkan pergerakan mendapatkan penilaian tertinggi. Hal ini dapat dilihat pada saat memesan makanan atau melakukan pembayaran tergolong dapat dilakukan dengan lancer. Yumaju Coffee memiliki area indoor untuk dan non smoking area dan outdoor untuk smoking area. Meskipun luas tanah Yumaju tidak begitu luas, namun penataan ruangan dan tata letak barang yang menarik serta memberikan kenyamanan kepada pelanggan yang berkunjung. Hal ini sejalan dengan pendapat Lee (2014), bahwa tata letak atau akses yang mudah dapat meningkatkan mutu layanan secara signifikan serta sebagai penentu kepuasan. Furnitur yang digunakan memenuhi fungsi dan kenyamanan, dan jarak antar kursi ditata sedemikian rupa agar tidak menghalangi akses jalan. Yumaju Coffee juga memberikan fasilitas wife gratis dan stop contact yang memadai.

Penilaian terendah dari spatial layout and funcionality terdapat pada indikator ketersediaan tempat parkir yang kurang memadai. Penilaian terhadap indikator tersebut didukung oleh data demografis responden yang diketahui bahwa sebanyak 47\% pengunjung Yumaju Coffee didominasi oleh pegawai. Lalu, sebanyak 54\% responden diketahui berpenghasilan lebih dari Rp 4.000.000, yang umumnya sudah memiliki kendaraan roda empat atau dua sehingga merasa tempat parkir tersebut belum memadai.

Dimensi sign, simbol dan artefacts memiliki nilai mean 4,21, artinya secara keseluruhan dimensi ini termasuk dalam katagori "sangat baik". Indikator yang memiliki nilai mean terbesar adalah sign, simbol and artefacts 1, dimana disain bangunannya menarik. Nilai pernyataan tersebut adalah 4,32 atau termasuk ke dalam kategori "sangat baik". Sedangkan, indikator sign, simbol dan artefacts 3 memiliki nilai mean terendah namun masih dalam katagori baik yaitu bahwa pegawai bersih dan rapih. Nilai mean instrumen tersebut adalah 4,12 yang tergolong "baik". Nilai standar deviasi yang diperoleh 0,593 atau sebesar $14,08 \%$. Angka tersebut masih berada di bawah $20 \%$ yang mengindikasikan bahwa responden memiliki tingkat variasi jawaban yang rendah dan menjawab pernyataan relatif sama.

Indikator disain bangunan Yumaju mendapatkan nilai sangat baik dari responden. Disain bangunan Yumaju di area outdoor menjadi ciri khas tersendiri yang membuat konsentrasi pengunjung akan ke area tersebut. Didominasi beton, dengan nuansa kayu dan besi serta pohon-pohon besar yang 
ada, ditambah dengan lantainya dialasi kerikil di suatu bagian dan alas sintetis di bagian lainnya, memberikan kenyamanan bagi pengunjung untuk duduk berlama-lama dan memanfaatkannya untuk berfoto. Selaras dengan hasil demografi responden, diketahui bahwa sebanyak $49 \%$ responden didominasi oleh remaja di rentang usia 21-25 tahun, yang mana menjadikan cafe sebagai gaya hidup di kalangan milenial. Berbagai aktifitas seperti membaca buku, melakukan rapat/meeting atau hanya sekedar berinteraksi dengan teman dapat dilakukan di cafe. Ditambah dengan maraknya kegiatan fotografi dan sosial media akhir-akhir ini menjadi minat bagi masyarakat khususnya di kalangan remaja. Masyarakat dapat mengunduh dengan mudah foto bangunan yang mereka datangi atau sekedar berbagi moment. Hal tersebut yang dimanfaatkan oleh Yumaju Coffee dengan menyediakan spot-spot menarik bagi pengunjung untuk berfoto, salah satunya dari desain bangunannya untuk membuat para pengunjung menjadi tertarik. Hal tersebut sejalan dengan pendapat Fitzsimmons (2011), bahwa reka bentuk bangunan yang menarik akan menimbulkan respon yang baik terhadap para pengunjung dan karyawannya. Indikator-indikator lainnya termasuk baik seperti keunikan dekorasi ruangan yang menyenangkan dan menarik bagi pelanggan dan penampilan pegawai yang memiliki ciri khas menggunakan kaos hitam, bersih, rapih, dan ramah.

\section{Hasil Analisis Deskriptif Variabel Loyalitas Pelanggan}

Analisis deskriptif terhadap variabel loyalitas pelanggan untuk mengidentifikasikan tingkat loyalitas pelanggan, yang hasilnya dapat dilihat tabel di bawah ini.

Tabel 3. Statistik Deskriptif Variabel Loyalitas Pelanggan

\begin{tabular}{|l|c|c|c|c|c|}
\hline & $\mathrm{N}$ & Minimum & Maximum & Mean & Std. Deviation \\
\hline Loyalitas_Pelanggan1 & 100 & 2.00 & 5.00 & 4,01 &, 732 \\
\hline Loyalitas_Pelanggan2 & 100 & 2.00 & 5.00 & 3,94 &, 750 \\
\hline Loyalitas_Pelanggan3 & 100 & 2.00 & 5.00 & 4,06 &, 750 \\
\hline Loyalitas_Pelanggan4 & 100 & 2.00 & 5.00 & 3,45 &, 989 \\
\hline Loyalitas_Pelanggan & $\mathbf{1 0 0}$ & $\mathbf{2 . 0 0}$ & $\mathbf{5 . 0 0}$ & $\mathbf{3 , 8 5}$ &, $\mathbf{8 0 5}$ \\
\hline Valid N (listwise) & 100 & & & & \\
\hline
\end{tabular}

Mengacu pada Tabel 3, indikator-indikator variabel loyalitas pelanggan mempunyai nilai mean 3,85 yang termasuk dalam katagori "tinggi". Indikator loyalitas pelanggan 3 sebesar 4,06 yang termasuk pada kategori "tinggi". Berisikan bahwa pelangggan yang pernah berkunjung merekemondasikan Yumaju Coffee kepada orang lain. Sedangkan, dimensi yang terendah adalah dimensi loyalitas pelanggan 4 yang menyatakan bahwa akan tetap memilih Yumaju Coffee dibanding coffee shop lain, namun masih dalam katagori "tinggi" dengan nilai mean sebesar 3,45. Nilai standar deviasi diperoleh $20,9 \%$. Angka tersebut berada di atas $20 \%$, menunjukkan bahwa responden memiliki variasi jawaban yang agak tinggi atau menjawab pernyataan relatif berbeda.

Indikator refers other yaitu memberikan rekomendasi kepada orang lain untuk berkunjung ke Yumaju Coffee memiliki nilai tertinggi sebesar 4,06 dan tergolong kategori "baik". Hal tersebut menandakan bahwa pelanggan yang datang merasa puas dengan produk dan jasa yang mereka gunakan selama berkunjung ke Yumaju Coffee, sehingga mereka dengan senang hati memperkenalkan dan merekomendasikan kepada pihak lain untuk datang ke Yumaju Coffee.

Penilaian yang memiliki nilai mean lebih kecil dibanding indikator yang lain terdapat pada demonstrate an immunity to the pull of competitor yaitu tetap memilih Yumaju Coffee daripada yang lain sebesar 3,45. Hal tersebut menunjukkan keinginan konsumen untuk tetap datang ke Yumaju belum mampu mencapai kategori sangat baik. Maraknya coffee shop di Bandung yang mengusung tema berbeda untuk menarik perhatian konsumen, membuat Yumaju Coffee harus terus meningkatkan kekuatan atau ciri khas dengan cara memperlihatkan faktor-faktor yang membedakan keunikan yang dimilikinya. Diantaranya dari segi konsep cafe yang dikemas secara baik dan modern sehingga setiap pengunjung yang datang ke Yumaju Coffee akan memperoleh suasana yang berbeda yang tidak akan didapat di tempat lain. Contohnya, dari segi produk yang ditawarkan, harga yang ditetapkan, lokasi yang mudah dijangkau, promosi yang menarik dan suasana yang bisa dikatakan nyaman untuk bersantai. Hal tersebut sesuai dengan pendapat Renald Kasali (2013), mengemukakan bahwa "ngopi" 
kini bukan sekedar untu menghilangkan kantuk, tapi sebagai bagian dari gaya hidup, dimana coffee shop menjadi tempat hangout yang sangat diminati.

\section{Peran Servicescape Terhadap Peningkatan Loyalitas Pelanggan}

Dalam menganalisis bagaimana peran servicescape dalam meningkatkan loyalitas pelanggan, maka diperlukan beberapa pengujian. Hasil analisis korelasi untuk melihat koneksi antara variabel servicescape dengan variabel loyaitas pelanggan, yang disajikan dalam tabel berikut ini.

Tabel 4. Hasil Analisis Uji Korelasi

\begin{tabular}{|l|l|c|c|}
\hline \multicolumn{2}{|c|}{} & Servicescape & Loyalitas Pelanggan \\
\hline \multirow{4}{*}{ Servicescapes } & Pearson Correlation & 1 &, $617^{* *}$ \\
\cline { 2 - 4 } & Sig. (2-tailed) & &, 000 \\
\cline { 2 - 4 } & $\mathrm{N}$ & 100 & 100 \\
\hline \multirow{3}{*}{ Loyalitas Pelanggan } & Pearson Correlation &, $617^{* *}$ & 1 \\
\cline { 2 - 4 } & Sig. (2-tailed) &, 000 & 100 \\
\cline { 2 - 4 } & $\mathrm{N}$ & 100 & \\
\hline \multirow{2}{*}{$* *$. Correlation is significant at the 0.01 level (2-tailed). }
\end{tabular}

Tabel 4 menunjukkan, nilai korelasi yang diperoleh berjumlah 0,617. Jika dilihat pada tabel interpretasi korelasi De Vaus, angka tersebut berada pada interval 0,50-0,69 (hubungannya kuat). Nilai Pearson Correlation menunjukkan nilai yang positif, menandakan adanya hubungan kedua variabel tersebut secara searah. Artinya, jika servicescape meningkat, maka loyalitas pelanggan pun ikut meningkat. Nilai signifikan yang diperoleh dari hasil korelasi antar kedua variabel tersebut adalah $0,000<0,05$, yang artinya terdapat korelasi yang signifikan. Adapun dengan melihat dari nilai $\mathrm{r}$ hitung (Pearson Correlations), diketahui nilai $\mathrm{r}$ hitung untuk hubungan serviescapes dengan loyalitas pelanggan adalah sebesar 0,617 > $\mathrm{r}$ tabel $0,196(\mathrm{~N}=100, \mathrm{sig}=5 \%)$ sehingga terdapat hubungan antara kedua variabel tersebut. Dari keseluruhan data yang telah diujikan kepada 100 responden meliputi pengunjung Yumaju Coffe di Kota Bandung, diperoleh hasil yang menunjukkan terdapat hubungan antara servicescape dengan loyalitas pelanggan. Hal ini dibuktikan dengan hasil analisis korelasi yang diperoleh 0,617. Angka tersebut pada tabel interpretasi korelasi De Vaus berada pada interval 0,50-0,69 yang memiliki arti bahwa hubungan kedua variabel tersebut kuat.

Hasil analisis uji regresi sederhana dilakukan untuk memprediksi besaran nilai variabel loyalitas pelanggan yang dipengaruhi oleh variabel servicescape dapat dilihat pada tabel berikut ini.

Tabel 5. Hasil Analisis Uji Regresi

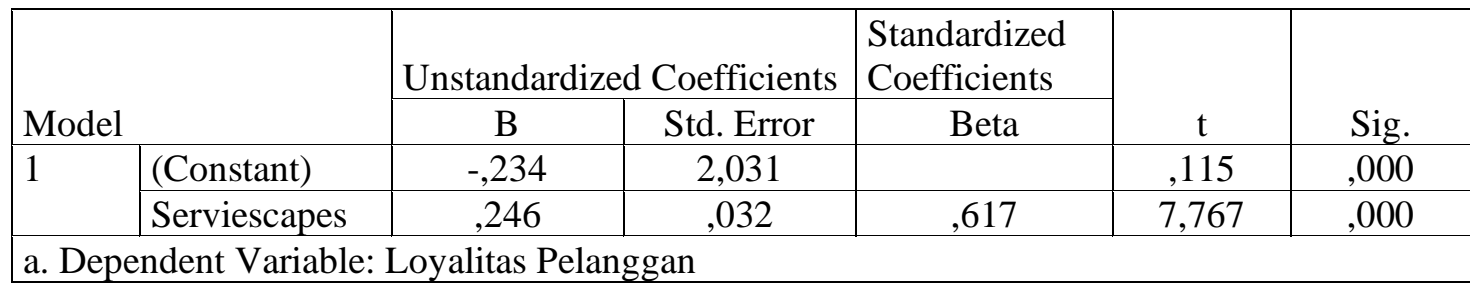

Mengacu pada Tabel 5, diketahui bahwa konstanta (a) bernilai -0,234 dan koefisien regresi (b) bernilai 0,246 dengan perhitungan seperti di bawah ini :

$$
\begin{gathered}
Y=a+b x \\
Y=-0,234+0,246 x
\end{gathered}
$$

Nilai a dan $b$ pada persamaan tersebut dapat diartikan banwa :

a. Konstanta (a) -0,234 diartikan bahwa jika tidak ada serviescapes ( $x=0)$, maka terjadi penurunan loyalitas pelanggan dengan nilai sebesar $-0,234$. 
b. koefisien regresi sebesar 0,246 memiliki arti bahwa setiap penambahan satu angka servicescape dengan koefisien bernilai positif, mengakibatkan kenailan loyalitas pelanggan sebanyak 0,246.

Selain itu, dari output pada tabel terlihat bahwa tingkat signifikasi $0,000<0,05$, menandakan bahwa model regresi dapat dipakai untuk memprediksi loyalitas pelanggan.

Hasil uji koefisien determinasi untuk mengukur seberapa jauh kemampuan variabel independen (servicescape) dalam menerangkan variabel dependen (loyalitas pelanggan) diperoleh sebagai berikut:

Tabel 6. Hasil Analisis Koefisien Determinasi

\begin{tabular}{|l|l|l|c|c|}
\hline Model & $\mathrm{R}$ & $\mathrm{R}$ Square & Adjusted R Square & Std. Error of the Estimate \\
\hline 1 &, $617^{\mathrm{a}}$ &, 381 &, 375 & 2,089 \\
\hline \multicolumn{4}{|l}{ a. Predictors: (Constant), Servicescapes } \\
\hline
\end{tabular}

Berdasarkan output Tabel 6, nilai $R$ Squarevdiperoleh 0,381 atau sama dengan 38,1\%. Artinya, bahwa variabel servicescape $(\mathrm{X})$ berpengaruh terhadap variabel loyalitas pelanggan (Y) sebesar 38,1\%. Sementara sisanya sebesar $61,9 \%$ dipengaruhi oleh variabel atau faktor yang tidak dijelaskan dalam penelitian.

Presentase peran yang diberikan servicescape terhadap loyalitas pelanggan adalah sebesar $38,1 \%$. Temuan uji verifikatif ini menambah varian penemuan dari beberapa peneliti sebelumnya yang menyatakan adanya peran antara servicescape dan loyalitas pelanggan bersifat positif dan signifikan (Aristianti, 2016) serta lingkungan fisik yang terdiri atas spatiality, amenity, aesthetics \& entertainingness memberikan pengaruh yang positif terhadap loyalitas pelanggan (Maeng \& Park, 2015).

Selanjutnya, dilakukan uji t untuk menguji hipotesis penelitian tentang terdapat tidaknya peranan yang signifikan varibel servicescape terhadap loyalitas pelanggan, hasilnya tersaji dalam tabel berikut ini.

Tabel 7. Hasil Uji-T

\begin{tabular}{|l|l|c|c|}
\hline \multicolumn{2}{|c|}{ Model } & $\mathrm{t}$ & Sig. \\
\hline \multirow{2}{*}{1} & (Constant) &, 115 &, 000 \\
\cline { 2 - 4 } & Servicescape & 7,767 &, 000 \\
\hline \multicolumn{2}{|c|}{ a. Dependent Variable: Loyalitas Pelanggan } \\
\hline
\end{tabular}

Berdasarkan Tabel 7, didapat:

1. Nilai signifikansi (sig) variabel servicescape adalah sebesar 0,000. Karena nilai Sig. 0,000 < probabilitas 0,05 , maka $\mathrm{H} 1$ diterima dan Ho ditolak. Artinya terdapat peran servicescape (X) terhadap loyalitas pelanggan (Y).

2. Nilai thitung variabel serviescapes adalah sebesar 7,767. Karena nilai $t$ hitung 7,764 >t tabel 1,984, maka dapat disimpulkan bahwa H1 diterima dan Ho ditolak. Artinya, adanya peran servicescape $(\mathrm{X})$ terhadap loyalitas pelanggan $(\mathrm{Y})$.

Jadi servicescape memiliki peran yang signifikan untuk meningkatkan loyalitas pelanggan.

Dalam pengujian deskriptif, diperoleh bahwa servicescape berada dalam katogori baik dan loyalitas pelanggan di Yumaju Coffee tergolong tinggi, sehingga bisa diartikan bahwa Yumaju Coffee adalah sebuah usaha yang tidak berorientasi secara instan/pragmatis. Hal ini mengindikasikan bahwa Yumaju Coffee adalah coffe shop yang tidak hanya berfokus untuk menjual kopi sebagai produk utamanya, tetapi menyediakan pula fasilitas yang membuat pengunjung dapat menikmati, menghabiskan waktu untuk mencari kenyamanan dan bersantai dengan suasana yang modern.

\section{Kesimpulan}

Kesimpulan dari hasil pembahasan penelitian terhadap pelanggan Yumaju Coffee di Kota Bandung adalah sebagai berikut:

Pertama, servicescpe yang telah dibangun oleh Yumaju Coffee yang meliputi ambient conditions, spatial layout and functional, serta sign, symbol, and artefact termasuk dalam katagori baik.. Dimensi 
yang sangat baik adalah sign, symbol, dan artefac terutama disain bangunan Yumaju Coffee yang memiliki ciri khas yang menarik. Namun tingkat kebisingan cukup mengganggu pelanggan terutama pada waktu banyak pengunjung dan di area outdoor yang lokasinya di pinggir jalan.

Kedua, loyalitas pelanggan yang diukur dengan indikator pembelian berulang, pembelian di luar lini produk atau jasa, merekomendasikan kepada orang lain, dan kekebalan terhadap daya tarik pesaing termasuk dalam katagori tinggi. Indikator yang paling tinggi yaitu merekomendasikan kepada orang lain untuk berkunjung ke Yumaju Coffee. Sedangkan yang paling rendah adalah indikator akan tetap memilih Yumaju Coffee walaupun masih banyak coffee shop yang lain.

Ketiga, servicescape memiliki peran yang signifikan terhadap loyalitas pelanggan sebesar $38,1 \%$, sementara sisanya sebesar $61,9 \%$ ada faktor-faktor lain yang berperan.

\section{Daftar Pustaka}

Bitner, M.J. (1992). Servicescape: The Impact of Physical Surroundings on Customers and Employees. Journal of Marketing, Vol 56, 57-71.

Darviansyah, Ivan. (2016). Kualitas Komunikasi Personal dan Servicescape Pengaruhnya terhadap Loyalitas Pelanggan Menggunakan Jasa Transportasi Bus Damri. Artikel.FE Universitas Komputer Indonesia. Bandung.

Demoulina, N \& Willemsb, K. (2019). Servicescape Irritants and Customer Satifaction: The Moderating role of Shopping motives and Involvement. Journal of Business Reseach, Vol.104, November 2019, pages $295-306$.

Dinas Koperasi, UKM, Perindustrian Perdagangan Kota Bandung. (2018). Rencana Strategis Dinas Koperasi, UKM, Perindustrian dan Perdagangan Kota Bandung Tahun 2010 2018. Bandung: Diskukm dan Perindag.

Fitzsimmons, J.A. \& Fitzsimmons, M, J. (2011). Service Management:Operation, Strategy, Information Technology, $7^{\text {th }}$ Edition.The McGraw-Hill: International Edition.

Hair, J.F. et al. (2010). Multivaiate Data Analysis (7th Edition). New York: Prentice Hall International, Inc.

Halim, A \& Matondang, A.R \& Lubis, A.N. (2019). The Effect of Merchandise and Serviscape on Customer Loyalty Through Customer Satisfaction at PT Gloria Jaya Sejahtera Medan. IOSR Journal of Business and Management (IOSR-JBM) Vol. 21, Issue 4, Ser.III (April 2019) page 69 -81 .

Hanaysha, J. (2016). The Importance of Social Media Advertisements In Enhancing Brand Equity: A Study on Fast Food Restaurant Industry in Malaysia. International Journal of Innovation, Management And Technology, Vol.7, No. 2, 46-51.

Hightower, R.Jr \& Shariat, M. (2009). Servicescape Hierachial Faktor Structure Model. Global Review of Business and Economic Research, 5(2),375-398.

Juliana \& Nouval, T. (2020). Pengaruh Servicescape terhadap Loyalitas Konsumen di Restoran Chakra The Breeze Bumi Serpong Damai. Jurnal Ecodemica, Vol 4, No.1, April 2020.

Kaihatu, T.S. (2007). Pengaruh Servicescape dan Perilaku Peran Ekstra Karyawan serta Kualitas Komunikasi Karyawan terhadap Kepuasan dan Loyalitas Pelanggan Hotel Bintang Empat dan Lima di Bali. Repositori, Universitas Airlangga.

Kotler, P \& Keller, K.L. (2012).Manajemen Pemasaran Perspektif Asia. Buku Pertama. Andy Yogyakarta.

Lee, S.Y \& Kim, J.H. (2014). Effect of Servicescape on Perceived Service Quality, Satisfaction and Behavioral Outcomes in Public Service Facilities. Journal of Asian Architerture and Building Engineering.

Liua, S.Q \& Bogicevicb, V \& Mattila, A.S. (2018). Circular vs Angular Servicescape: "Shaping"customer response to fast service encounter pace. Journal of Business Reseach, Vol. 89, August 2018, pages $47-56$.

Lovelock, C \& Wirtz, J. (2011). Sevices Marketing: People, Technology, Stategy, 7th Edition, Prentice Hall.

Lunardo, R \& Roux, D \& Chaney, D. (2016). The Evoking Power of Servicescapes: Consumers' Inferences of Manipulativ Intent Following Service Environment-Driven Evocations. Journal of Business Reseach, Vol. 69, Issue12, Desember 2016, pages 6097 - 6105. 
Maeng, H \& Park, J. (2015). A Study on the Effect of Physical Environment in an Airplan on Customer Loyalty. Journal of Airline and Airport Manajemen.2015-5(2), 81-100.

Oktafani, F \& Suryawardani, B \& Riezkya, A.D. (2016).Groundzero's Café Bandung Customer Satisfication Influence on Servicescape. BANDUNG CREATIVE MOVEMENT 2016. |Multidisciplinary Design: Harmonizing design in today's society, technology and business. Telkom University.

Ongkohadi Y.H. (2014). Perancangan Interior Magnum Kafe di Surabaya) Program Studi Desain Interior. Universitas Kristen Petra. Vol 2, No.2, hal 421-425.

Pratama,M.K \& Setyorini, R. (2015). Pengaruh Servicescape terhadap Kepuasan Konsumen Kafe Roti Gempol dan Kopi Anjis Cabang Jalan Bengawan Bandung. e-Proceeding of Management, Vol. 2, No. 1 April 2015, page 749.

Putri, E.N \& Sunarti \& Pangestuti,E. (2018). Pengaruh Servicescape terhadap Kepuasan dan Loyalitas Pelanggan, (Survei pada Pelanggan Toko Oen Malang). Jurnal Administrasi Bisnis (JAB) Vol. 62 No. 1 September 2018 administrasibisnis.studentjournal.ub.ac.id 63.

Rahman, R.A. \& Kusuma, H.E. (2014). Definisi Kebetahan Dalam Ranah Arsiterktur danLingkungan Perilaku. Prosiding Temu Ilmiah IPLBI 2014. Program Studi Teknik Arsitektur. Palembang: Universitas Sriwijaya.

Shashikala, R \& Suresh, A. (2013). Building Consumer Loyalty Through Sevicescape in Shopping Malls.IOSR Journal of Business and Management (IOSR-JBM), Vol.10, Issue 6 (May-Juni 2013), pages $11-17$.

Srivasta, M \& Rai, A.K. (2018). Mechanics of Engendering Customer Loyalty: A Conceptual Framework. IIMB Managemnt Review, Vol. 30, Issue 3, September 2018, pages 207 - 218.

\section{*Email korespondensi:}

maya.setiawardani@polban.ac.id 